Pregledni članak UDK 101.9(045)

1 Pejović, D.

doi: $10.21464 /$ fi3 39207

Primljeno: 20. 2. 2019.

\title{
Mladen Živković
}

Galija 1, HR-21480 Vis

mlazivko@inet.hr

\section{Danilo Pejović - učitelj mišljenja}

\begin{abstract}
Sažetak
Iako ne jedini, Danilo Pejović pokazao je kako je bilo moguće misliti drugačije, otvarati perspektive, otvarati se budućem, izlazeći iz marksističke kabanice kojom smo gotovo svi bili zaogrnuti. U svojoj osobi utjelovio je izvorni filozofski etos i golemu erudiciju. Snaga njegova mišljenja očituje se u istančanoj analizi predmeta. Očit je njegov literarni talent kojim se nadaje kao virtuoz i umjetnik riječi, mjestimice poetičnoga stila. Pejović s lakoćom govori o najtežim temama filozofije. Svagda piše jasno, poučno i entuzijastično odmjerenim, probranim i profinjenim izričajem, po čemu nadilazi sve naše filozofske pisce. To iščitavamo već u naslovima njegovih knjiga, studija, eseja i članaka koji govore dubinom svoga smisla, sabirući u sebi smisao čitavoga teksta. Pejović dokazuje kako se moglo evoluirati ususret nadolazećem, novom i drugačijem. Naravno, to novo i drugačije nije samim time već tu, ali za otvaranje novih obzorja trebamo ići protiv struje. Opus Danila Pejovića treba uzeti kao smjerokaz koji nas upućuje da se zdušno pozabavimo sami sobom, da pred sobom položimo račun sami sebi o tome kako je s nama bilo, kako jest i kako treba biti. Njegovo promišljanje teme hrvatske nacionalne sudbine, viđeno kroz promišljanje hrvatske baštine, kulture, povijesti, društva i politike, iznijelo je na zavidnoj misaonoj razini angažiranog filozofa s kojim se kod nas malo tko može usporediti. Upravo mu danas za to dugujemo zahvalnost $i$ služi mu na čast kako je pristupio tom tematskom krugu. Nama su ta njegova razmišljanja nezaobilazna i obvezujuća. Mislimo da je upravo sada pravi trenutak za iščitavanje njegova opusa u cjelini, a ovog aspekta osobito. Ovim kratkim osvrtom htjeli smo tek ukazati na njegov doprinos našoj filozofiji i kulturi. Pejović svakako ostaje iznimno aktualan i poticajan. Nadamo se da je ovim radom to dovoljno obrazloženo. Ako bi ovaj tekst potaknuo naše mlade filozofe i filozofkinje da prionu proučavati njegova djela, onda bi ovaj rad ispunio svoju svrhu. Neka do njih dopru njegove riječi, riječi učitelja mišljenja, da »mišljenje živi samo na taj način da ustraje u traganju i pitanju«.
\end{abstract}

\section{Ključne riječi}

Danilo Pejović, filozofija, povijest, znanost, tehnika, estetika, kultura, otvorenost, hrvatska kultura

\section{Uvod}

U prvom dijelu rada, ${ }^{1}$ dan je sažeti uvid u tematska područja kojima se profesor Danilo Pejović bavio. U drugom dijelu izdvajamo njegove misli o hrvat-

Izlaganje održano 29. rujna 2018. godine na Cresu u sklopu simpozija »Hrvatska filozofija u interakciji i kontekstu«, 27. Dani Frane Petrića. Povod je bila devedeseta godišnjica rođenja profesora Danila Pejovića (Ludbreg, 1928. - Zagreb, 2007.). Ovo je skromni prilog podsjećanju na Pejovića, koji je nastao iz zahvalnosti što sam ga imao čast slušati i od njega učiti. O njemu je malo pisano. Izdvajam zbornik povodom 80. godišnjice Pejovićeva rođenja: Lino Veljak (ur.), Filozofija i suvremenost -Zbornik radova s konferencije povodom 80. obljetnice rođenja Danila Pejovića, FF-press, Zagreb 2010. 
skoj povijesti, kulturi, književnosti, filozofiji i suvremenim temama. Raspon tih tema kreće se od politike do kulturnog stvaralaštva. U njima upoznajemo Pejovića kao filozofa i angažiranog intelektualca, kada nije bio samo promatrač s distance nego je uzeo aktivnoga učešća u zbivanjima. Podsjećanje na taj dio njegova opusa važno je ne samo zbog prigode spomenute obljetnice nego, ponajprije, i zbog aktualnosti svekolikih njegovih misli, a o ovom tematskom bloku osobito. Naime, za razliku od hrvatskih filozofa koji su bili njegovi suvremenici, osobito onih okupljenih oko časopisa Praxis, od kojih se većina nije bavila tim pitanjima ili, ako su to činili, pisali su o tome kroz vizuru marksizma i stigme nacionalizma, kod Pejovića nalazimo iznimno vrijedne radove u kojima ulazi u filozofsku elaboraciju aktualnih prijepora da bi nakon toga pružio jasan uvid u aktualna zbivanja, njihova ishodišta $\mathrm{i}$ tendencije. Pejović je tim svojim tekstovima otvorio teme o kojima vrijedi danas i ubuduće dalje promišljati, naprosto zato jer su mnogi problemi na koje je ukazivao još uvijek otvoreni. Tim njegovim tekstovima stvaramo pretpostavke za neophodno suočavanje nas samih danas s nama samima, da bismo dali svoj stvaralački doprinos pri iznalaženju odgovora na mnoga pitanja s kojima smo suočeni kao pojedinci, kao intelektualci, kao društvo u cjelini, uključujući tu i institucije pa i samu državu. Izazovi s kojima se suočavamo uistinu su veliki.

\section{O filozofiji}

Čini se prikladnim odmah se na početku prisjetiti Pejovićevih teza o samoj filozofiji. U početku je njegovo shvaćanje filozofije pod utjecajem Marxa i njegove teze o ozbiljenju filozofije i ukidanju proletarijata. Tako čitamo:

»Filozofija se dijalektički ukida (aufhebt) samo tada kada se potpuno obistini, i kad zbiljnost sama postane istinita (filozofska). $\ll^{2}$

Reći će još da je Marxova ideja o ostvarenju filozofije njegova središnja misao na kojoj počiva Marxova »velebna misaona zgrada $\ll .{ }^{3}$ Kasnije suodređuje filozofiju i umjetnost kao govorenje iz iskona sviju stvari. Osobito lijepim i biranim riječima o tome piše $u$ »Dijalogu o ljubavi i smrti « kada kaže:

»Tako potreba filozofije izrasta iz sama srca čovjeka koji je izgubio svoje obitavalište u srcu stvari, odakle ga je vrijeme povijesti iščupalo. $\ll^{4}$

Govor umjetnosti i filozofije može čuti samo onaj koji nije oglušio od buke. Pejović poetski kaže da je tihi govor mišljenja o iskonu i smislu poput one tišine kojom priroda govori pjesniku, pa citira stih Dobriše Cesarića: »Tiho, o tiho govori mi jesen $(\ldots) . \ll^{5}$

»No filozof (...) je svagda na putu, (...) njega obuzima čežnja za onim što je ‘jedino mudro' u heraklitovskom smislu, i u tome je draž njegove sudbine nikad završenog traganja za smislom, istinom i bitkom. $\ll^{6}$

Malo kasnije, reći će kako filozofija treba otkloniti od sebe ulogu tješiteljice, zbaciti jaram sluškinje, nekoć doduše teologije, ali danas znanosti i politike.

»Ona mora ostati samobitna djelatnost i slobodna od bilo kakve neposredne 'primjene', pa čak i od fizike i matematike koje su joj najbliže još od najstarijih vremena. « ${ }^{7}$

Filozofsko mišljenje ne smije se poimati kao sredstvo za nemisaone svrhe, nego kao ono koje ima svoju svrhu u sebi. Suvremenim hrvatskim filozofima poručuje da se trebaju suočavati s istim onim problemima s kojima se suočavaju filozofi u svijetu, da budemo u 
»... dijalogu s velikim misliocima prošlosti. Bez toga nema ništa. ${ }^{8}$

Bila je to njegova poruka u razgovoru objavljenom u časopisu studenata filozofije Čemu. Tako će biti naslovljena i njegova zadnja knjiga. Prihvatiti nam je tu njegovu smjernicu za razumijevanje filozofije, baš danas i ovdje kad nam se nudi toliko nadomjestaka istinskog filozofskog mišljenja. Njegovo shvaćanje filozofije možda je najsažetije i najbitnije iskazano u tezi:

»Jer filozofija je manifestacija slobode - ili nije ništa. « ${ }^{9}$

\subsection{Povijest filozofije}

Danilu Pejoviću dugujemo zahvalnost što nam je približio i omogućio jasan uvid u mnoštvo značajnih imena svjetske filozofske baštine. Podsjećam ovdje na knjige Francuska prosvjetiteljska filozofija ${ }^{10}$ i Suvremena filozofija zapada. ${ }^{11}$ U uvodu knjige Suvremena filozofija zapada Pejović pojašnjava pojmove »suvremenost « $\mathrm{i} \gg$ Zapad «, za koje je ustvrdio da nisu ni u kom slučaju samorazumljivi, nego u mnogome prijeporni te ih rasvjetljava na način koji je i danas zanimljiv, znakovit i važan za našu temu jer su ti pojmovi još uvijek u matici intelektualnih tema naše suvremenosti. Pojam suvremenosti nije istoznačan s današnjicom. To suvremeno je, $\mathrm{s}$ jedne strane, prema

»... svojoj biti već dovršeno i prošlo, iako naprosto po inerciji još uvijek žilavo traje i dalje pruža grčevit otpor prolaženju. Obratno, ono što je odista suvremeno, mukotrpno sebi probija put iz budućnosti u sadašnjost. «12

Radi se o sukobu staroga i novoga "ponavljanja prošlosti i prihvaćanja iskonske budućnosti «. ${ }^{13}$ Obje tendencije sadržane su u suvremenoj zapadnoj filozofiji. Pojam »Zapad« nije zemljopisni nego civilizacijski i kulturološki pojam koji baštini grčku antiku, kršćansko srednjovjekovlje i moderno građansko društvo. Taj je Zapad iznjedrio modernu kapitalističku ekonomiju, znanstvenu spoznaju i strojnu tehniku koji se danas globaliziraju. Ovdje valja podsjetiti da nam je danas plodonosno analizirati njegovu polemiku u ovoj knjizi s još-ne-filozofijom kao anti-filozofijom, onda kada Pejović izlaže teze znanstvenog empirizma, neopozitivizma, analitičkog filozofiranja i osobito

Danilo Pejović, Realni svijet: temelji ontologije Nicolaja Hartmana, Nolit, Beograd 1960., str. 201.

3

Danilo Pejović, Protiv struje, Mladost, Zagreb 1965., str. 12. 4

Danilo Pejović, Sistem i egzistencija: um $i$ neum u suvremenoj filozofiji, Zora, Zagreb 1970., str. 259.

5

Ibid., str. 49.

Danilo Pejović, Duh i sloboda: ogledi i rasprave, Hrvatsko filozofsko društvo, Zagreb 1992., str. 20.

7

Ibid., str. 25.
Tomislav Medak, Petar Milat, Petar Šegedin, »Razgovor s Danilom Pejovićem: U dijalogu s velikim misliocima prošlosti«, С̌етu 2 (1995) 6, str. 103-111, str. 111.

9

D. Pejović, Sistem i egzistencija, str. 220.

10

Usp. Danilo Pejović, Francuska prosvjetiteljska filozofija i odabrani tekstovi filozofa, Nakladni zavod Matice hrvatske, Zagreb 1982.

11

Danilo Pejović, Suvremena filozofija zapada i odabrani tekstovi filozofa, Matica hrvatska, Zagreb ${ }^{3} 1982$.

12

Ibid., str. 7.

13

Ibid. 
logičkog pozitivizma. Jedna je od karakteristika njegova pisanja upravo ironija koja ovdje dolazi do punog izražaja:

»Ukoliko su takva nastojanja puka posljedica nedostatne misaone obrazovanosti treba im dobrohotno dati elementarnu filozofsku pouku. «14

No ukoliko nastupaju agresivno protiv mišljenja koje nije znanstveno, utoliko im valja »bez predumišljanja razotkriti primitivizam njihova meta-fizičkog ishodišta «. ${ }^{15}$ Pejović u polemici s logičkim pozitivizmom nastupa kao učitelj mišljenja i razvidno pokazuje svu ishitrenost i proturječnost takvih nastojanja na primjeru Rudolfa Carnapa, za kojega tvrdi da:

»... ne može domisliti svoju vlastitu pretpostavku, jer bi to njegovu filozofiju definitivno učinilo nemogućom i neodrživom. Razlog je u tome što on nije u stanju da spozna dijalektiku osjetilnog iskustva i same filozofije. On nije shvatio što sam čini, tj. da je svaki empirizam pa i njegov vlastiti već jedna svojevrsna 'metafizika', što (...) proizlazi iz biti same stvari, iz prirode filozofskoga mišljenja. ${ }^{16}$

\section{Kritika Carnapa sažima se u tezi:}

»Stav 'Znanost je jedina istina svijeta', nije znanstven, nego metafizički. «17

Za hiperprodukciju Bertranda Russella, koji je dobio Nobelovu nagradu za književnost, kaže da ga vjerojatno ne bi dobio da se dodjeljuje za filozofiju. Njegova kritika Nicolaija Hartmanna sažima se u tezi:

»Takvo filozofsko mišljenje koje se svjesno ograđuje od 'svjetonazornog opredjeljenja' i samo 'nepristrano promatra' bitak ne može uspjeti u tome da bude povijesno, ostaje po strani od biti vremena i ne otvara nikakvu perspektivu. ${ }^{18}$

\section{Kritika pak Jaspersa:}

»Zanimljivo kao simptom pristupa svijetu koji ne škrtari riječima, to se mišljenje rastvorilo u slatkorječivosti. ${ }^{19}$

U knjizi Sistem i egzistencija, znakovita podnaslova »um i neum u suvremenoj filozofiji«, Pejović piše o suvremenim filozofima gdje ponovo dolazi do izražaja njegova maestralna upućenost u opuse filozofa i teme kojima se bave. Pri tome dolazi do izražaja njegova velika erudicija, lakoća i jasnoća izraza koja nas zadivljuje. U tekstu »Dijalektički preokret apsolutne fillozofije « čitamo izvanredan esej o Schellingu, koji završava riječima:

»Djelo koje nam je ostavio u baštinu neiscrpno je poticajima na novo razmišljanje. «20

Doista poticajno za ozbiljnije bavljenje ovim kod nas pomalo zapostavljenim filozofom njemačkog klasičnog idealizma. Izvrsnim i također poticajnim nalazimo njegove tekstove »Egzistencijalna dijalektika ili - ili« o Kierkegaardu. ${ }^{21} \mathrm{O}$ filozofiji egzistencije Pejović kaže da osvještava nehumanost, besmisao i nihilizam građanskog svijeta, pri čemu ukazuje na pojavne oblike njegova potpunog otuđenja. Ona se javlja prvi put kod kasnoga Schellinga, potom Sørena Kierkegaarda, Arthura Schopenhauera i Friedricha Nietzschea. Freudom se Pejović bavi u tekstu »Otuđenje i otkupljenje «. ${ }^{22}$ Freudu pristupa kao kritičaru građanskog društva - superkonzumnog totalitarizma - i vjesniku nove reforme, mrzitelju filozofije i ideologu »emancipiranih« malograđana! Potom Pejović podsjeća na neke važne kategorije toga čudnoga »fiziološkometafizičkog razmišljanja«, po kojem je čovjek »u biti biološko i iracionalno biće, a njegova je 'duša' posve nagonske prirode ${ }^{23}$ Pejović s pravom zamjera Marcuseu što Freuda stavlja uz bok takvih mislilaca kao što su Aristotel i Hegel. No ne možemo se složiti s Pejovićem kada u taj niz još uvijek stavlja Marxa. Zadnjom svojom knjigom Veliki učitelji mišljenja Pejović piše o Pla- 
tonu, Aristotelu, Descartesu, Spinozi, Kantu, Hegelu, Detlevu von Uslaru i Heideggeru. Treba primijetiti da su sva ovdje spomenuta imena neosporno veliki učitelji mišljenja, osim von Uslara. Bilo bi zanimljivo istražiti zašto ga Pejović stavlja u taj niz, ali ovdje nije mjesto o tome raspravljati. Ovdje svakako treba spomenuti njegove izvrsne studije o Aristotelu, Hegelu, Kantu i Nietzscheu. Pejović je od početka svojeg filozofiranja u stalnom dijalogu s Heideggerom. Piše njime potaknut, ali ponekad i polemično. S njim se susretao i sudjelovao u seminarima. Objavio je tekst razgovora s Heideggerom, a donosi i neka osobna svjedočanstva. ${ }^{24}$

\subsection{Filozofija umjetnosti}

U sažetom, sustavnom, preglednom, inspirativnom i briljantnom tekstu-predgovoru antologiji tekstova Novija filozofija umjetnost ${ }^{25}$ Pejović nudi uvid u stanje umjetnosti tijekom 20. st. Teško se tu odlučiti za citat jer svaka je rečenica bremenita značenjem i smislom koji rasvjetljava sudbinu ne samo suvremene umjetnosti nego i suvremenog čovjeka jer riječ o umjetnosti uistinu je riječ o čovjeku. Tako kaže, nakon što je odmjeravao suvremenu umjetnost $\mathrm{u}$ njenom odnosu spram prirode, tehnike, oblika, zbilje, osjećajnosti, razumljivosti i slobode:

»Kada se bitak otuđi od bića u svijetu, onda je sva umjetnost otuđena, pri čemu se nesloboda njezina može očitovati kao samovolja ili kao nasilje nad njom. Dehumanizacija i depersonalizacija čovjeka popratne su pojave toga jedinstvenoga procesa bludnje povijesti, i nitko ne može predskazati dokle će taj svijet razularene tehnike biti poprište prijepora suprotnih svjetonazora $i$ totalitarnih ambicija vladavine nad planetom. Skončavanje staroga i započinjanje novoga svijeta traje veoma dugo, još smo uvijek svi samo svjedoci toga doba sveopćeg prijelaza. ${ }^{26}$

Pejović raspravlja o temi iščezavanja religije i umjetnosti u njihovu dotadašnjem značenju, kako je to već navijestio Hegel. Dok se mnogi slažu da je doista tako s religijom, o odumiranju umjetnosti ima i suprotnih viđenja. Pejović navodi Hegela, Marxa i Heideggera kao jednako aktualne mislioce o toj temi. Tim nekritičkim pridavanjem značenja Marxu o ovoj temi tek na osnovu jednog konfuznog pasusa $u$ »Prilogu kritici političke ekonomije« Pejović je

14

Ibid., str. 17.

15

Ibid.

16

Ibid., str. 23.

17

Ibid., str. 30 .

18

Ibid., str. 92.

19

Ibid., str. 108

20

D. Pejović, Sistem i egzistencija, str. 86. 21

Usp. ibid., str. 88-96.

22

Usp. ibid., str. 141-159.
23

Ibid., str. 147.

24

Usp. Danilo Pejović, Oproštaj od moderne. Heideggerovo razumijevanje novoga vijeka, Matica hrvatska, Dubrovnik 1993., str. 159-164; usp. Danilo Pejović, Veliki učitelji mišljenja, Naklada Ljevak, Zagreb 2002. U knjizi Sistem i egzistencija objavljen je njegov razgovor s Martinom Heideggerom. No valja imati na umu da Pejović često piše o Heideggeru u mnogim drugim tekstovima. Sustavni prikaz bio bi zadatak za jednu posebnu i zanimljivu studiju. Usp. D. Pejović, Sistem i egzistencija, str. 116-127.

25

Danilo Pejović (ur.), Novija filozofija umjetnosti, Nakladni zavod Matice hrvatske, Zagreb 1972.

26

D. Pejović, Duh i sloboda, str. 59. 
još marksist, koji prema Marxu nema eksplicitnu kritičku distancu. Epohe povijesti estetike samo odgovaraju glavnim etapama povijesti metafizike.

»U djelu umjetnosti bića stupaju u neskrivenost svoga bitka, umjetničko djelo u sebi sabire i začinje jedan povijesni svijet. Kao sebe-u-djelo postavljanje istine bitka umjetnost je bitno sačinjanje kako glasi stara riječ za pjesništvo. ${ }^{27}$

\title{
Na kraju kaže:
}

»Sada smo bliže razumijevanju biti umjetnika: obraćen zavičajnoj budućnosti kao pjesnik, umjetnik je vjesnik obrata istine bitka i mora ostati tuđinac u otuđenom svijetu. To je znao i hrvatski 'regionalni' pjesnik Fran Galović, pjevajući:

\author{
... 'poznaš ovo nebo, zvezde ove \\ I ovo zemlo, kaj te k sebe zove!' \\ Preveć dobro poznam se kraj sebe to, \\ Zato ne mrem pota najti vre domo. 'Kostanj' « 28
}

Citiranjem tih stihova htjeli smo ukazati na Pejovićev smisao za istinsko pjesništvo i to na primjeru našeg pjesnika koji ne ulazi u skupinu onih najpoznatijih, ali kojega Pejović prepoznaje kao filozofski relevantnog.

\subsection{Znanost, tehnika, rad}

Odnos znanosti, tehnike i rada prema filozofiji stalna su preokupacija Danila Pejovića. Ovdje samo u skici navodimo njegove najvažnije teze koje trebaju biti jedno od nezaobilaznih polazišta za naše današnje daljnje bavljenje tim temama. U radu »Antička i suvremena znanost « ${ }^{29}$ Pejović kaže da filozofija prethodi svakoj pojedinačnoj znanosti, a to onda znači da nije njihova sinteza. Baš zato što filozofija, kao znanje o biću kao biću, ima u vidu cjelinu bića kao bića mogu se pojaviti posebne znanosti koje se konstituiraju obrnutim putem »svraćanja pogleda « od cjeline, ograničavajući se na jedno područje bića. Utemeljenje matematike i fizike prati utemeljenje prve filozofije, kako $\mathrm{u}$ antici tako i u novom vijeku. Novovjekovna znanost, smatra Pejović, počinje prevratom, osporavanjem Aristotelova autoriteta i afirmacijom baštine Platona i neoplatonizma u renesansi (Marsilio Ficino, Frane Petrić, Giordano Bruno) i njihovu poimanju ontološkog statusa matematičkog bitka. Preobrazba novovjekovnoga duha, po mišljenju Pejovića, ide od filozofije prema znanosti, matematiziranoj prirodnoj znanosti i tehnici koja se dovršava u kibernetici. To dovodi do postupnog tehniziranja svekolike prakse. Tehnika postaje vladajućim odnosom čovjeka prema prirodi i drugom čovjeku. Tako matematika, fizika i atomska tehnika preuzimaju vodstvo u oslobađanju materije i energije kako bi ih izručile na raspolaganje tehničkom zahvatu. Po mišljenju Pejovića, tri su moderne predrasude o znanosti:

1. Znanost je jedino legitimno znanje i put istini naspram neopravdanih pretenzija filozofije i onih oblika duha što nisu i ne mogu biti znanost.

2. Kao dominirajući oblik svijesti ona pokazuje tendenciju neograničenog napretka.

3. Takav neograničeni napredak znanosti jamstvo je napretka povijesti i boljitka svijeta. To je prosvjetiteljski optimizam.

Pejović ohrabrenje vidi u činjenici da je znanost postala svjesna svoje filozofske i povijesne dimenzije, o čemu svjedoči kopenhaška interpretacija kvantne teorije (Niels Bohr, Werner Heisenberg, Carl Friedrich von Weizsäcker).

U »Tehnici i metafizici ${ }^{30}$ čitamo da je čovjeku kao biću pripadno tehničko odnošenje. No dok je u antici tehnika kao techne imala šire značenje i 
obuhvaćala obrt, rukotvorstvo, lijepu umjetnost, tj. sve ono što nije prirodno samoniklo jest blisko umjetničkoj produkciji, s time da se obrt može naučiti, a umjetnička produkcija ne može. Za Aristotela, pored theoria i praxis, techne je najniži oblik odnošenja prema svijetu. Porijeklo moderne tehnike valja tražiti u novovjekovnoj filozofiji koja počinje Descartesom, kada ujedno počinje epohalna mijena u svim mogućim odnosima novovjekovnog čovjeka prema svijetu, tj. prema prirodi, samom sebi, društvu i povijesti. Rezultat je te mijene da se priroda javlja kao korisni materijal za tehniku. Priroda se poima kroz mehanički ustrojen mehanizam, a ta riječ potječe od grčke riječi mecha$n e$, što znači oruđe. Taj mehanizam prirode pojmljiv je kroz prirodne zakone (Newtonov zakon gravitacije). Za Aristotela priroda je samonikla fysis. Antička tehnika raspolaže oruđima (kolotur, poluga, čekrk, katapult itd.). U suvremenosti se tehnika javlja kao ingeniozno lukavstvo uma (lukavi je isto što i hudi, tj. đavao) koji nadmudruje prirodu. Moderna tehnika je strojna tehnika. Ona beskrajno napreduje u usavršavanju svojih proizvoda (najbolja slika je računalna tehnika $i$ »komunikacijska« tehnika). Ona je totalitarna. Tehnika je tako izraz apsolutne volje za moći čovjeka koji hoće gospodariti svijetom. Politika se pretvara u tehniku (staljinizam kao strojna država, pseudonim Staljin dolazi od njemačke riječi Stahl (čelik), a Molotov od ruske riječi molot, što znači čekić). Politika je postala vještina učinkovitog manipuliranja masama kao tehničkom sirovinom. Masa je središnja kategorija suvremene fizike.

Zadatak je filozofijskog mišljenja ukazati na potrebu oslobađanja od tehnicizma i tehnologije mišljenja. Treba osporiti tendenciju da tehnika postane metafizika - produljenje života tada, a danas raznorazni transhumani projekti. Pejović na to upućuje komentiranjem da »sferu humaniteta valja osloboditi od svakog tehničkog silovanja «. ${ }^{31}$ Zajedno s Pejovićem upitamo: ako današnje čovječanstvo ne može više bez tehnike, kako dalje s njom i je li moguća jedna prirodi sklona tehnika? Ili drugim riječima, kako bi današnji čovjek mogao postati prirodi, pa time i sebi samom, skloniji čovjek?

\subsection{Filozofija jezika}

Pejovićeva razmišljanja o filozofiji jezika nalaze se u tekstu »Jezik kao iskustvo svijeta «, podnaslova »nacrt za jednu filozofiju jezika «. ${ }^{32} \mathrm{Na}$ ovom mjestu nije potrebno ulaziti u širu elaboraciju toga teksta. Pejović ukazuje na nedostatnost suvremenih pristupa jeziku, a osobito znanstvenog pristupa. Tema jezika za Pejovića nadilazi svaku znanstvenu i filozofsku disciplinu. U tom tekstu do punog izražaja dolazi njegova umješnost u jasnom i čitkom pisanju baš kad se bavi najsloženijim temama. Svatko tko bude kod nas pokušao filozofski razmišljati o jeziku trebati će proučiti taj relativno kratki, ali spoznajama i uvidima u narav jezika prebogat tekst. Pejović je taj rad nazvao nacrtom u kojem nabacuje teze, dok je njihovo opsežno izvođenje ostavio za drugu priliku, što se nikada nije ostvarilo.

27

D. Pejović, Protiv struje, str. 133. 28

Ibid., str. 134.

29

Usp. D. Pejović, Oproštaj od moderne, str. 83-99.

30

Usp. D. Pejović, Protiv struje, str. 43-69.
31

Usp. Danilo Pejović, Hermeneutika, znanosti i praktična filozofija, Veselin Masleša, Sarajevo 1982., str. 132-170.

32

Usp. ibid., str. 204-211. 


\subsection{Marksizam}

Na početku svoga stvaralaštva Pejović veliča Marxa kao epohalnog mislioca. $\mathrm{S}$ vremenom postaje odmjereniji u prosudbi, a nakon razlaza s filozofima praksisovcima primjetna je njegova sve veća distanca od marksizma koju iščitavamo u »Nedorečenim tezama o Marxu i marksizmu « iz 1970. godine. ${ }^{33}$ Mogli bismo reći da tom godinom kulminira njegovo pisanje o Marxu i marksizmu, ali ni ovdje ni kasnije nije ga analizirao i raspravljao onako sustavno, kritički i analitički kao druge filozofske tendencije i filozofe 20. stoljeća. To nisu uradili ni praksisovci. Oni su doduše bili za kritiku svega postojećega, osim svoje pozicije i samog Marxa! Uglavnom su se iscrpljivali u kritici devijacija od autentičnog marksizma (birokratskoga socijalizma, staljinizma), pri čemu su sebe vidjeli kao neprijeporne autentične marksiste. U tekstu »Egzistencijalizam u Hegela«, Pejović iznosi zanimljivu tezu da su egzistencijalizam i marksizam nastali iz pukotina sustava Hegelova apsolutnog idealizma. Marksizam i egzistencijalizam razvijaju se kao dva suprotstavljena oblika povijesnih tendencija našega vremena. U »Dva marksistička pristupa Hege$1 \mathrm{u} \ll^{34}$ (tekst pisan sedamdesetih godina 20. st.), Pejović kaže da je marksizam jedan od dominantnih nazora o svijetu. Marxova misao prodorna je jer njenu jezgru čini revolucionarna dijalektika koja se temelji u Hegelu. Za Pejovića je Lenjin (veliki praktičar) prvi koji je marksizam kao filozofsku teoriju proveo u konkretnu političku praksu, koji u tišini Berlinske biblioteke marljivo proučava »mističke spekulacije« apstraktnog Hegela te ističe da je Lenjin u svojoj oporuci tražio da marksisti postanu materijalistički prijatelji Hegelove dijalektike. Marksisti Lenjinovu oporuku, kaže Pejović, ispunjavaju nekih četrdesetak godina nakon njegove smrti radovima Györgyja Lukácsa Mladi Hegel i Povijest i klasna svijest, Ernsta Blocha Subjekt - objekt, i to nakon renesanse Hegela u »građanskoj filozofiji«! Pejović ukazuje na neprihvatljivost Lukácseva podcjenjivanja bavljenja Hegelom kod »građanskih filozofa « te navodi kako je za njih Lukács kazao da su njihova istraživanja »reakcionarnofašističke laži«! Ipak, za Lukácsevu Povijest i klasnu svijest drži da je vrijedna i da postaje nezaobilazna u bavljenju Hegelom. Zatim analizira Blochovo djelo Subjekt - objekt. Pejović kaže da je i kod Blocha vidljivo posezanje za etiketiranjem drugačije mislećih građanskih filozofa koji Richarda Kronera smješta u fašiste-iracionaliste, a taj je, kaže Pejović, emigrirao 1933. godine u Sjedinjene Američke Države. Pejović piše o Blochu u tekstovima »Pojam napretka kod Ernsta Blocha «, 35 »Potraga za bitkom kao hermeneutika nade «,, 36 »Kasna žetva« ${ }^{37}$ Pejović ističe Blochove zasluge, ali ukazuje na njegovo veličanje Lenjina i cionizma (»Ubi Lenin ibi Jerusalem«) i ustrajni staljinizam. Smatra da se pogrešna interpretacija Marxa kao tehničara zbiva u staljinizmu u kojem se filozofija ostvaruje kao tehnika, kao planska tehnizacija Rusije:

»... ovo je bilo moguće samo na temelju totalne ili apsolutne organizacije politike, privrede i svih sfera sovjetskog života uopće: sve treba da je planirano i kalkulirano iz jednoga apsolutnoga centra opredmećeno i postvareno u obzoru racionalne organizacije svijeta kao tehničkog sistema. Svi 'sektori' zbiljnosti funkcioniraju kao dijelovi jednoga stroja, čija pokretna snaga i osovina nastupa kao Vođa sam. $\ll^{38}$

Pejović proročanski navješćuje mogućnost da »kineski komunizam «s vremenom nadiđe i sam staljinizam - zar nismo svjedoci da Kina postaje najmoćnije svjetsko gospodarstvo? Za kineski komunizam kaže da će se dovršiti u karikaturi svuda prisutnog totalnog besmisla zbivanja. Izgradnja proizvodnih snaga nije cilj socijalizma, nego je to nužnost nerazvijenih država, počevši od Jugoslavije, preko SSSR-a, do Kine! »Nedorečene teze o Marxu i marksizmu« tekst je koji je nastao povodom 150. godišnjice Marxova rođenja. Ostaje 
aktualno ono što je tada rekao. Naime, pojmovnik Marxova Kapitala za današnju zbilju (onu 1970-tih, a treba dodati i ovu na kraju dvadesetih godina 21. stoljeća) neprimjeren je, bile te kategorije preuske ili preširoke.

»Historijski materijalizam valja primijeniti $i$ na sam historijski materijalizam. Živi pristup Marxu mogu danas ostvariti samo oni koji mu prilaze kritički (...). Zbiljnost je već izvršila demitologizaciju marksizma. ${ }^{39}$

Pejović je kritički progovorio o mnogim misliocima, pa i o marksistima Blochu, Lukácsu i drugima koji su se pozivali na Marxa kao njegovi sljedbenici i epigoni. Pisao je o staljinizmu i maoizmu, o »pomahnitaloj utopiji« 1968. godine, ali o Marxu i marksizmu ostao je nedorečen! Pejović je pred kraj svog misaonog i životnog puta došao do zaključka da spomenuta imena ne može staviti u probrano društvo velikih učitelja mišljenja, najvećih i najznačajnijih mislilaca. Dakako, bilo bi zanimljivo istražiti kako je bilo moguće da su Marx i marksisti, globalno i kod nas, bili filozofski autoriteti prvoga reda. Je li tomu bio razlog samo postojanje tzv. socijalističkog bloka država pa su njihovim urušavanjem kao povijesne stranputice istu sudbinu doživjeli i autoriteti koji su im bili ideološka i politička osnova? No treba naglasiti, svojim je opusom Danilo Pejović stvorio pretpostavke za današnji hrvatski filozofski pristup tom dijelu naše filozofske baštine koji je bitno odredio našu svakodnevicu, naše živote, društvo, politiku, kulturu, umjetnost te društvene i humanističke znanosti od 1945. do 1990. godine. To je dugo vremensko razdoblje. Još u nama ustrajavaju ostatci svakojakih strahova, neslobode, građanske pasivnosti, defetizma koji su dio toga »nasljeđa«. Dijelom zbog toga tako sporo i teško napredujemo u usvajanju građanske kulture i demokracije, slobode, poštivanja ljudskih prava, nenasilja itd. Trebalo bi na osnovu specifičnog hrvatskog iskustva ispisati »Dorečene teze o Marxu i marksizmu « jer ono što je do sada u tom smislu učinjeno nije dovoljno. Osobito imajući u vidu činjenicu da je marksizam ovdje bio nametan kao nedodirljiva ideologija. Možemo reći da su se tek sada za to stekle sve pretpostavke. Suočavanje s nama i kako je bilo s nama u tom razdoblju marksističkog ideološkog monopola nezaobilazni je preduvjet za iskorak u ono željeno drugačije, novo i bolje.

\subsection{Kritika kulture}

Kritika kulture stalna je Pejovićeva preokupacija. Eksplicitno ju pratimo od teksta $»$ Amerika kao ideal $\ll,{ }^{40} \gg$ Pomahnitala utopija $«,{ }^{41} \gg$ Oproštaj od moderne $\ll,{ }^{42}$ a implicitno je tematizirana u mnogim drugim esejima i studijama. Pejović tim naslovima ponire u bit duha vremena u kojemu je živio i saznajemo kako je maestralno iznio istinu epohe. Vrijednosti potrošačkog društva, o kojima piše u eseju »Amerika kao ideal«, postale su u međuvremenu globalni

33

Ibid.

34

Usp. ibid.

35

Usp. ibid., str. 160-176.

36

Usp. ibid., str. 177-196.

37

Usp. ibid., str. 197-203.
38

D. Pejović, Protiv struje, str. 18.

39

D. Pejović, Sistem i egzistencija, str. 205.

40

Usp. D. Pejović, Protiv struje, str. 161.

41

Usp. D. Pejović, Duh slobode, str. 91-120.

42

Usp. D. Pejović, Oproštaj od moderne, str. 173-197. 
ideal, pa tako i u svim postkomunističkim državama. Sporadične neosmišljene pobune, kao ona 1968. godine ili ove kojima svjedočimo, samo su izljevi gnjeva građana koji su nezadovoljni svojim participiranjem u potrošnji. Svijet se oprašta od moderne i ide u neizvjesnost. Prijeti mu urušavanje u mnogim sferama koje je moderna prepoznala, ali krize i problemi koje je uočila ostaju otvoreni. Idu kulminaciji s neizvjesnim ishodom. Pejović ih identificira kroz krizu države, ekološku krizu, krizu napretka, krizu slobode i humanizma, političku krizu itd. I danas su izazovne njegove teze o ulozi intelektualaca, a osobito humanističke inteligencije. Za ovu sintagmu »humanistička inteligencija « tvrdi da je pleonazam! Povlačenje intelektualca u privatnost, smatra Pejović, znači pasti ispod razine poziva i sramotiti ga jer moć uvida u ono bitno dar je koji imaju tek rijetki pojedinci. Ta nejednaka obdarenost je nepremostiva razlika među ljudima koja tim više obvezuje intelektualce. Pišući o inteligenciji šezdesetih godina prošlog stoljeća Pejović se zapitao: »Zašto smo tako nedijalektički pozitivni? «. Pogađa li to pitanje hrvatsku inteligenciju i danas pri kraju drugog desetljeća 21. stoljeća? Pejović je upozorio još 1995. godine da je za male narode i države bijeg intelektualaca u ekonomsku emigraciju dugoročno poguban jer oni odlaze umjesto da budu prisutni u svojim sredinama. Na taj način otvaraju prostor za amatere koji nas udaljavaju od Europe i svijeta.

\section{Hrvatska povijest, baština i kultura}

Pejović otvara temu hrvatskog naroda, njegove baštine, kulture, povijesti, sadašnjosti i budućnosti, ali i njegove političke situacije u okviru SFRJ tijekom šezdesetih godina 20. stoljeća. Pejović se s praksisovcima, koji su bili njegovi kolege na Filozofskom fakultetu u Zagrebu, razilazi 1966. godine i napušta redakciju časopisa Praxis kojemu je bio urednik i suosnivač. Kraj šezdesetih i početak sedamdesetih godina 20. st. jest vrijeme kakvog-takvog popuštanja jugoslavenskog totalitarnog komunizma koje je rezultiralo Hrvatskim proljećem 1971. godine, u kojem je sam Pejović bio sudionik. Nakon toga uslijedilo je teško olovno vrijeme partijskog monopola. Tada su nastali za ovu temu najznačajniji radovi poredani prema vremenu nastanka. Prethodi im tekst »Smisao umjetničke pobune « iz 1965. godine, ${ }^{43}{ }$ Sveučilište i kultura « iz 1968. godine, ${ }^{44} »$ Nacionalizam i internacionalizam« iz 1969. godine,${ }^{45} \gg$ Književnost i politika « iz 1970. godine, ${ }^{46} »$ Bilo a nije prošlo« iz 1970. godine, ${ }^{47}$ »Zrinsko-frankopanska urota i hrvatska povijest« iz 1971. godine ${ }^{48} \gg$ Hrvatska kulturna orijentacija u 1971. godini« iz 1971. godine, ${ }^{49}$ »Otvorenost hrvatske kulture « iz 1971. godine. ${ }^{50}$ Osim teksta »Bilo a nije prošlo«, svi su ostali tekstovi prvi put ponovno objavljeni sabrani u knjizi Duh i sloboda ${ }^{51}$ i to tek 1992. godine. O sudbini tih tekstova, koji su ponovno objavljeni više od dvadeset godina nakon njihova nastanka, u bilješci na kraju knjige sam Pejović kaže:

»... jer kako i sami pokazuju, to iz poznatih razloga dosad nije bilo moguće. Koliko su tada kao ogledi i rasprave bili dorasli zadanoj stvari među ostalim svjedoče i netom napisani reci u Epilogu o sudbini što nas je zadesila dvadeset godina kasnije: Dubrovnik kao metafora. «52

Toj se temi vratio dvadeset godina kasnije tekstovima u spomenutom »Epilogu « u jeku Domovinskoga rata. To su tekstovi: »Filozofi starog Dubrovnika« iz 1992. godine ${ }^{53} »$ Svrha od slobode ${ }^{54}$ iz 1992. godine.

Možda će se netko upitati čemu u 21. stoljeću staviti naglasak baš na ove tekstove koji su nastali najvećim dijelom prije pedeset godina? Tomu je više razloga: 
1. Govoriti o Hrvatskoj filozofiji u interakciji i kontekstu evociranjem Danila Pejovića u prigodi 90. godišnjice njegova rođenja osobito je prikladno.

2. Ti su tekstovi najvećim dijelom i danas aktualni, na što će biti posebno ukazano, jer u njima nalazimo mnoge poticaje za razumijevanje i promišljanje naše duhovne situacije danas.

3. Pejović te tekstove piše u vrijeme marksističke partijske ortodoksije. Njima je iskoračio u svoju specifičnu disidentsku poziciju. Danas nam je od posebne važnosti čitati njegove tekstove o toj temi, kao i tekstove drugih naših filozofskih pisaca, književnika, teologa itd., jer su postali baština koja je poticajna za nove iskorake i popudbina za suočavanje s izazovima ovoga vremena.

4. Nastankom međunarodno priznate samostalne Republike Hrvatske početkom devedesetih godina, sada početkom 21. st. mogli bismo »podvući crtu « $\mathrm{i}$ osvrnuti se na proteklo razdoblje da bi sebi postavili neotklonjiva pitanja: Jesmo li u dosluhu s našom baštinom u kojoj opus Danila Pejovića ima važno mjesto? Jesmo li htjeli biti to što smo i kako smo sada? Znamo li kamo idemo? Jesmo li kao građani i kao narod subjekti na svom putu ili smo ponovno objekt tuđih interesa? Ako netko ima dvojbi pri promišljanju odgovora na ta pitanja čitanja ovih tekstova sigurno će mu pomoći!

5. Konačno, ako bi netko prigovorio da te teme nisu uobičajene filozofske teme ili da nemaju filozofsku relevantnost, tada treba naglasiti da su one eksplikacija filozofskog promišljanja i da imaju svoju filozofsku osnovu i relevantnost. O njima piše vrstan filozofski znalac i erudit, a osobito naglašavamo: za istinske mislioce nema velikih i malih tema. Bavljenje tzv. velikim temama i imenima iz svjetske filozofske baštine ne jamči unaprijed da pothvat ne bi mogao doživjeti neuspjeh. Dapače, veliki antički mislioci polazili su na svoj stvaralački put iz svog »malog « svijeta, iz polisa koji nije bio megalopolis.

Danilo Pejović je šezdesetih godina 20. st. uočio posebnost i stvaralački doseg hrvatskih pregalaca u književnosti, povijesti i filozofiji.

\subsection{Smisao umjetničke pobune}

Pejović 1964. godine u eseju »Smisao umjetničke pobune« promišlja hrvatsku povijesnu sudbinu i ona od tada ostaje konstanta u njegovu opusu do zadnjega intervjua. Pejović tu piše o Krleži kao umjetniku i pjesniku Balada Petrice Kerempuha:

43

Usp. D. Pejović, Protiv struje, str. 303-325. Usp. ibid., str. 155-160.

44

Usp. D. Pejović, Duh i sloboda, str. 83-90.

45

Usp. ibid., str. 123-136.

46

Usp. ibid., str. 139-146.

47

Usp. D. Pejović, Sistem i egzistencija, str. 235-248.

48

Usp. D. Pejović, Duh i sloboda, str. 147-153.
49

50

Usp. ibid., str. 161-172.

51

Usp. ibid.

52

Ibid., str. 191.

53

Usp. ibid., str. 175-184.

54

Usp. ibid., str. 185-188. 
»Ali je samo jedan od naših umjetnika u sadašnjem trenutku takav da na jedinstven način otkriva istinu našega naroda i svojom pobunom označuje smisao ove epohe. To je Miroslav Krleža. $\ll^{55}$

To otkrivanje istine hrvatskoga naroda stalni je zadatak intelektualaca, a posebno filozofa, pa tako i danas. Otkrivanje istine najvažniji je zadatak filozofije. Zatim, u tom tekstu čitamo znakovite riječi:

»... socijalni bunt može uspjeti samo kao nacionalna pobuna protiv svih onih koji su u prošlosti vladali Hrvatskom. To su u prvom redu Beč i Pešta, ali ne manje oni koji su Balade 1936. u Ljubljani dali zaplijeniti, ukratko, svi neprijatelji Hrvatske. $\ll^{56}$

Vrijeme pobuna i ratova za opstojnost, nadamo se, duboko su iza nas, kao i da je konačno došlo vrijeme da više neće biti kako je »navek bilo«: neprestano strašno stradanje, ratovanje i pogibanje. Izazovi koji danas prijete nisu ništa manje opaki. Svjedoci smo ugrožene supstancije vitaliteta naroda, propadanja i izumiranja čitavih subregija iz posve drugih razloga, iako na granice naših prostora naviru izbjeglice koje nas podsjećaju na naše povijesno »antemurale christianitatis «. Naš narod je, kaže Pejović, »stoljetnim ratovima toliko iskrvario te umalo potpuno nije zbrisan s lica zemlje «. ${ }^{57}$ Tom komadanju Hrvatske u okviru Habsburške Monarhije bili su pridonijeli i domaći pristranici strane vlasti.

»Djetinjski naivna, naša nacionalna svijest sporo sazrijeva i teškom se mukom probija kroz nepregledne naslage laži i vjekovnih zabluda. $\ll^{58}$

Nama se ovdje nameće pitanje: blude li naši narodni vođe sada u Bruxellesu umjesto u Beču, Pešti, Beogradu? Malo dalje Pejović piše:

»Tragična je povijest našega maloga naroda kroz stoljeća i nema tih riječi koje bi je mogle dovoljno snažno opisati. Utoliko više što je književnost uglavnom ignorirala pitanja narodnog oslobođenja. $« 59$

Te riječi napisao je Danilo Pejović prije skoro pola stoljeća kada nitko nije slutio raspad socijalizma, a još manje raspad SFRJ četvrt stoljeća kasnije u krvavom ratu. Te riječi su time dobile svoju zadnju tragičnu potvrdu u ratu i stradanju kao hrvatskoj konstanti i sudbini. Može li hrvatska povijest u 21. stoljeću biti predmet filozofskog promišljanja ili ju treba ostaviti povjesničarima? Danilo Pejović nam je pokazao da je on kao filozof imao što reći hrvatskom narodu o njegovoj povijesnoj sudbini, pa samim time i budućnosti.

\subsection{Bilo a nije prošlo}

»Bilo a nije prošlo« studija je koja je za naš rad osobito važna i zapravo iznimno aktualna. Moramo se složiti s Pejovićem i zapaziti da suvremenici koječemu pridaju povijesno značenje, kao da ne znamo što je povijest i ono povijesno u razlici spram puko prolaznog, uobičajenog i svakodnevnog. Također se valja s njim složiti kad kaže da tradicionalni modeli metafizike i filozofije povijesti nisu dorasli dati odgovor na predstojeće izazove.

»Filozofsko mišljenje tu se sukobljuje s nesavladivim teškoćama. «60

U odnosu spram tradicije sučeljavaju se tradicionalisti koji ju samo veličaju i modernisti koji ju posve odbacuju. No, po mišljenju Pejovića, jednako je besmisleno tradiciju zbrisati, isto tako kao što je besmisleno održavati umjetno na životu ono što je mrtvo jer nije sve staro najbolje samo zato što je staro, kao što nije sve novo najbolje samo zato što je novo. Tradicija se uspostavlja inovacijom i obrnuto. Tradicija je bitak onoga što bijaše, a inovacija je zahvaćanje budućnosti u sadašnjost. Ovdje nam je potrebno zastati i priupitati 
se što je nama ta tradicija, baština itd. Je li ona tek etnografska zbirka mrtvih artefakata, arhaičnim jezikom ispisana književnost koja je suvremenicima nečitka, a mladima beživotna, dosadna i zastarjela? Je li sva potpuno mrtva ili u njoj ima još barem nečega živog? Ima li u njoj nečega što može biti suvremeno i što će ostati baština onom što tek dolazi? Ontologija nas poučava, kaže Pejović, da se samo ono postojano može mijenjati. Što je to u našoj baštini i tradiciji što je postojano i što ostaje? Odgovor na to pitanje moguć je ako obratimo pozornost na ontološku strukturu vremena i povijesti. Po mišljenju Pejovića, tri su moguća načina razumijevanja vremena i tri tipa vremena. Jedino humano vrijeme čovjeka i njegova djelovanja, koje je teleološki usmjereno prema budućnosti, sjedinjuje u sebi sve oblike temporalnosti, kao ono po svojoj naravi povijesno. Zato čovjek ima pored radnog dana, koji se ravna satnim mehanizmom, i blagdan:

»Čovjek blaguje blag-dane kad bilo koja tradicija biva neposredno prisutna.« ${ }^{61}$

Valja nam se povodom ovdje rečenoga zapitati o tome kako blagujemo baštinjene blagdane. Čini nam se da se i u tome ogleda svojevrsna i osebujna kriza njihova identiteta i smisla, bilo da je riječ o religijskim ili svjetovnim blagdanima. Tradicija je tako prisutna u bitku čovjeka kao ona »buduća prošlost« koja prethodi svakoj sadašnjosti i budućnosti.

»... proteklo nas vrijeme od neke povijesne zgode ne samo ne udaljuje od prošlosti, nego nam je naprotiv približava, jer istinsko je vrijeme pravi temelj povijesnoga zbivanja, čovječjeg opstanka u svijetu i jedini zalog njegova smisla. Ukoliko dakle istinski shvatimo bit povijesnoga vremena, tradicija neće biti smetnja (...) nego saveznik i oslonac (...). Tradicija nije puko prošlo nego u svojoj biti svagda iznova nadolazi kao budućnost. «62

Govore li nam te riječi Danila Pejovića, imamo li za njih sluha? Danas smo u jednoj osobitoj povijesnoj prilici iznova prisvojiti svoju prošlost. Ne možemo biti suvremeni ako se zatvorimo spram prošlosti predaka. Kao »predaja povijesnoga iskustva mišljenja, djelovanja i umijeća tradicija je zbivanje između pokoljenja«. Ne treba posebno obrazlagati koliko su te Pejovićeve riječi aktualne. Dovoljno se prisjetiti proturječja, neslaganja i izraza otvorene međusobne netrpeljivosti oko pristupa i razumijevanja naše nedavne prošlosti. Zagovaratelji naslijeđenog pristupa povijesti one koji ju preispituju i reinterpretiraju nazivaju revizionistima. Koriste iskaz iz propalog marksističkog vokabulara kojima se diskvalificiralo i ocrnjivalo te time unaprijed opravdavalo proganjanje političkih neistomišljenika, bez nakane otvaranja kvalificirane akademske rasprave. S druge strane, tobožnji revizionisti, koji s pravom inzistiraju na reinterpretaciji te povijesti, misle da je dostatno učiniti razvidnim ono što je doskora bilo zabranjeno, kao da bi nas sama ta spoznaja, najčešće svireposti i zla, mogla osloboditi za iskorak u jedno istinski drugačije stanje društva i ono istinski novo. Oba pristupa pokazuju da smo posustali u nadilaženju svojih različitosti i da svaki od ta dva stava iskazuje tek jedan moment cjeline povijesne istine jer, po mišljenju Pejovića:

55

D. Pejović, Protiv struje, str. 311.

56

Ibid., str. 314.

57

Ibid.

58

Ibid., str. 315.
59

Ibid., str. 316.

60

D. Pejović, Sistem i egzistencija, str. 237.

61

Ibid., str. 242.

62

Ibid., str. 243. 
»Tradicija omogućuje kontinuitet (...) iskustva sa svijeta, priprema uvjete za Novo i smješta ga na pravo mjesto u cjelinu zbivanja povijesti. No upravo time, tom svojom neprispodobivom snagom, tradicija je uvijek ne samo dar vremena nego isti mah i prijetnja da se izgubi otvorenost za buduće, ona nas može dovesti i do ukrućivanja u bivšem, te tako do prividnog ovjekovječenja prošlosti. ${ }^{63}$

Potom kaže da sebe može potvrditi samo ono pokoljenje koje je otvoreno spram budućnosti Novog i prošlosti onoga Najdrevnijeg. Tradicija je tako ono staro što nikad nije posve staro niti zastaruje. Ona je sjećanje na mitsko i herojsko doba jednog naroda,

»... njegove kultove i rituale, u osebujnosti vjerskih, moralnih i pravnih običaja, autoritetu baštinjenih ustanova i ugleda velikih pojedinaca (...) pruža temelje za stabilnost društvenih i državnih ustanova, njihov ugled i čast, njihovu postojanost i ukazuje na smjer njihova daljeg razvitka. ${ }^{64}$

Ovdje je također potrebno ukazati na zaborav tih riječi. Svjedoci smo opravdanog nezadovoljstva s nama i našim suvremenim stanjem, ali također smo svjedoci olakog omalovažavanja svega i svačega, pojedinaca i institucija, te olakog zapadanja u krajnost posvemašnjeg negiranja i ostrašćenog rogoborenja koje zagađuje javni prostor. Na taj način ne možemo pridonijeti otvaranju perspektive za drugačije i bolje. Naprotiv, to nas zatvara za budućnost u koju se stiže otklonom od emocija, umišljenog znanja istine o svemu, svakomu i svačemu. Prepoznavanje onog živog i budućnosnog te onog mrtvog i prošlog u tradiciji moguće je u stvaralačkom naporu koji ne nastaje iz mržnje, jer ona može samo razarati, a nikako graditi. Pejović naglašava da tradiciju tvore autoriteti, štoviše, u nju spadaju i zajedničke predrasude, mitovi i zbiljski događaji, zgode i nezgode pojedinca, naroda i čovjeka uopće, a mogu ju prisvojiti samo stvaralački narodi i pojedinci koji mogu osjetiti puls povijesnoga tijeka, tj. oni narodi koji mogu sačuvati svoju povijesnu ravnotežu između prošlosti i budućnosti.

»Najintenzivnije pradavna prošlost, kao i ona najbliža, živi u takvim sferama duha kao što su umjetnost i filozofija. $\ll^{65}$

Ipak, ovdje bismo dodali: i u znanosti, religiji i narodnom stvaralaštvu, u glazbi, plesu i pjesmi itd. Potom Pejović niže imena iz klasične književnosti i filozofije sve do suvremenosti kako ne bi bilo zabune da on pledira samo za hrvatsku tradiciju. Štoviše, kaže da nije pretjerivanje ako kažemo da nam tradicija daje za pravo reći da mi danas možemo bolje razumjeti Platona i Aristotela, nego što su oni mogli razumjeti sami sebe! U tom kontekstu govori o novovjekovnim revolucijama u kojima se događa gnjevni prodor naprijed, prekid kontinuiteta tijeka povijesti, no ni one ne mogu bez povijesti i bez tradicije. Revolucija u prvoj fazi prekida s tradicijom, potom uviđa da ne može bez prošlosti, barem one svoje, da bi u trećoj fazi nastupila kao čuvar svoje tradicije, pa time i prošlosti kao takve. Očito je da je Pejović ovdje još uvjeren $\mathrm{u}$ ispravnost socijalističkog puta kao onoga na kojem hrvatski narod postaje povijestan.

»Povijesni pak ne možemo postati nikada ako ta budućnost sama već ne nadolazi $i$ iz prošlosti, pruža nam oslonac i pomaže nam da osmislimo svoj vlastiti trenutak odluke. «66

Stoga je na nama da kritički prisvajamo prošlo, koje je temelj svake inovacije i samobitnosti.

»Na nama je da se konačno probudimo iz nihilističkog drijemeža, da prevladamo pozitivistički zaborav tradicije i osvijestimo se svoje integralne pripadnosti svome zavičaju, narodu i Evropi, kako se to događa kod nekih drugih evropskih naroda. « ${ }^{67}$ 
Slijede njegove riječi koje djeluju proročanski, ako imamo u vidu da je tekst objavljen 1970., a da je Hrvatska postala članica Europske unije 2014. godine:

»Kao narod vlastite povijesti, kulture, imena i jezika, mi i sada, makar nedovoljno, prisustvujemo u svijetu, i budući da smo svoje konkretno mjesto u evropskoj povijesti izborili pred više od deset stoljeća, moramo napokon imati i smjelosti da kažemo otvoreno: ako mi nismo ništa bez Evrope, bez nas danas ni Evropa više ne bi bila Evropa. Suprotno svakom apstraktnom univerzalizmu, Evropa može biti zajednička domovina mnogih naroda samo kao jedinstvo mnogostrukog i raznolikog čuvajući pomno osebujnost i individualitet svakoga naroda koji sačinjava takvu Evropu. U takvoj pluralističkoj evropskoj povijesti izborili su naše mjesto već glagoljaši, pokazali što jesmo Marulić i Vitezović, ponovo nas otkrili Gaj i Mažuranić i našu prisutnost uvjerljivo potvrdili Kranjčević, Matoš i Krleža. Čemu da se toga odričemo, u ime čega da zatajimo sebe, zašto da i mi ne budemo ono što već odavno jesmo? « ${ }^{68}$

Čini nam se kako je baš danas zasjala sva ljepota i istina tih njegovih riječi. Dakle, valja promišljati kako nam je biti u toj zajednici europskih naroda kao samosvjestan narod, koji nije više objekt nego bi trebao biti subjekt zbivanja. Jesmo li subjekt ili objekt politike? Prihvaćamo li nekritički odluke ili sudjelujemo u njihovu donošenju? Jesmo li inicijativni i inovativni ili tek nekritički oponašamo i izvršavamo odluke? Napokon, jesmo li zaboravili svoja gorka iskustva s Europskom unijom i njenom sukrivnjom za razmjere naših stradanja od 1990. do 1995. godine? Taj Pejovićev tekst u cjelini i osobito onaj na kraju izdvojeni poduži citat daju povoda postavljanju sličnih pitanja. U svakom slučaju, Pejovićeve vizionarske riječi da se ne odričemo sebe, da ne tajimo sebe i da budemo dio europske zajednice naroda nama su danas obvezujuće, poticajne, ohrabrujuće i optimistične.

\subsection{O nacionalnoj kulturi}

U tekstu »Sveučilište i kultura« Pejović objašnjava kako nastaju tzv. univerzalne vrijednosti svjetske kulture te otklanja izlišno dijeljenje ili čak suprotstavljanje nacionalnih i svjetskih kulturnih vrijednosti.

»Vrijednosti svjetske kulture prije svega moraju biti nacionalne vrijednosti kulture pojedinog naroda, i ako to zaista jesu, onda samim tim u isti mah postaju i univerzalne vrijednosti (...). Svjetski su glas stekla pojedina sveučilišta tek nakon što su postala glasovita u svom zavičaju i široj domovini (...). Nema granica znanosti i umjetnosti, nema granica univerzalnosti kulture: ako je nacionalna i kultura, onda je svjetska i općeljudska (...). Svaki apstraktni univerzalizam koji mehanički odjeljuje nekakve isključive 'nacionalne' vrijednosti od tobožnjih 'svjetskih', ignorira činjenice i vodi u apsurd. Konkretni univerzalizam sastoji se u skladnom uzajamnom dopunjavanju kulture jednog naroda kulturama drugih i međusobnom otvaranju granica. ${ }^{69}$

Hrvatski renesansni mislioci imali su značajnu ulogu u stvaranju naše nacionalne i u isti mah univerzalne europske kulture.

»Kao mali narod možemo se ponositi tim našim prilogom svjetskoj kulturi potvrdivši time svoju intelektualnu zrelost i povijesnu suvremenost. $\ll^{70}$

63

Ibid.

64

Ibid., str. 244

65

Ibid., str. 245.

66

Ibid., str. 248
67

Ibid.

68

Ibid

69

D. Pejović, Duh i sloboda, str. 88.

70

Ibid. 
Potom Pejović navodi šest smjernica za reformu sveučilišta koje su i danas aktualne, od kojih izdvajamo:

»... njegovanje vlastitog govora (...) jer dobro poznavanje materinskog jezika neophodan je uvjet za prihvaćanje vlastite kulture (...), učenje stranih jezika ponajprije velikih europskih (...), a zatim arapskoga, hindi, i kineskog jezika $(. ..) . \ll^{71}$

Suočeni s prijetećim »nalijeganjem na jezik hrvatski« lingua franca-e globalnog engleskog jezika i e-medija, uočavamo kako je Pejović i ovdje bio vizionar koji nam poručuje da učimo svjetske jezike. U njegovom tekstu »Nacionalizam i internacionalizam « lako je uočiti da je pisan u mučnim okolnostima negiranja osebujnosti i posebnosti hrvatskog nacionalnog identiteta u vremenu u kojem je utjecajna dogmatska ideološka kritika diskvalificirala etiketama intelektualac i nacionalist. Pojašnjavajući nastanak nacionalnih pokreta, pa i hrvatskog, Pejović kaže da je svaki takav pokret težio samoodređenju i oslobođenju vlastitog naroda protiv bilo kakve dominacije te daje definicije zavičaja, domovine, domoljublja:

»Uža postojbina u kojoj se čovjek rodio zavičaj je njegov, a sva djedovina otaca i predaka njegovih to mu je domovina. $\ll^{72}$

Svaka nacionalna svijest korijeni se u ljubavi prema domovini i očituje se kao strastvena predanost,

»... nadirući iz najdublje nutrine duše, predanost onoj nadindividualnoj cjelini što kao poredak zajednice nosi svakog pojedinca (...). Spremnost na žrtvu i službu domovini (...). Nacionalna se svijest manifestira u poštivanju temeljnih nacionalnih simbola kao što su nacionalna zastava, himna, spomeni i blagdani, u pamćenju simboličkih likova nacionalne povijesti, obilježavanju velikih datuma i mjesta kao i vidnom javnom odavanju počasti.« ${ }^{73}$

Tako shvaćeno domoljublje bilo je gotovo sveprisutno u hrvatskom narodu u vrijeme Domovinskog rata, no ono ima svoju trajnu vrijednost i u miru jer je brana od primitivnog egoizma i pohlepe koji umiju beskrupulozno nadirati. Potom Pejović, govoreći o domovini, kaže da je ona odgovorno:

$» .$. preuzimanje jedne povijesne tradicije kao neponovljive osebujne vizije svijeta, čovjek prihvaća svoju narodnost uvijek na razuman i čuvstven način. «74

Dug je proces nastajanja nacionalne svijesti svakoga naroda.

»Ljubav prema svom narodu, težnja da on ostvari sva svoja prava u skladu s pravima svojih susjeda i poštujući njih kao i svoja vlastita - to je pravi patriotizam. «75

Nacionalizam je, po mišljenju Pejovića nastao, iz sacro egoismo della patria, stavljanjem pojedinačnih nacionalnih interesa i ciljeva ispred, iznad i protiv drugih naroda. Kao primjer navodi francusku nacionalističku organizaciju Action Française iz 1898. godine sa zadaćom ostvarivanja mistične vječne Francuske.

»Ukoliko nacionalizam postane još agresivniji i počne propovijedati sveti rat za oslobođenje, zazivati svetu osvetu itd., a sve u ime više rase, ili višeg naroda, onda poprima sve značajke šovinizma. ${ }^{76}$

Bili smo svjedoci tomu krajem osamdesetih godina 20. st. i tijekom Domovinskog rata. Pejović uočava da ni Marx ni Engels, kao osnivači komunističkog internacionalizma, nisu imali sluha za prava malih naroda na opstanak, a kamoli na slobodu i ravnopravnost s velikima:

»U svojim napisima o revoluciji i kontrarevoluciji u Njemačkoj i Evropi oni ističu svjetskopovijesno pravo velikih kulturnih naroda da asimiliraju male nekulturne ostatke naroda širom Evrope. $\ll^{77}$ 
Marxu i Engelsu predbacivan je njemački šovinizam. Na kraju Pejović govori o pravoj Domovini koja nadilazi svaku nacionalnu i internacionalnu ograničenost.

»Ta nas Domovina obvezuje jednako danas kao i sutra: u istinskom prijateljstvu s drugim narodima, gdje nitko neće imati pravo da bude manje solidaran s bitnim zahtjevima svoje rodne zemlje. ${ }^{78}$

\subsection{Književnost i politika}

U uvjetima totalitarizma Pejović poziva na snošljiv i prijateljski dijalog. Već 1969. godine kaže:

»... samo u tom sklopu moguć je slobodan i otvoren razgovor književnosti i politike, uzajamno poticanje i bogaćenje obostranih odnosa, kao zalog zajedničke ljudske budućnosti svih nas. Zar objema stranama ne bi bilo od koristi takvo novo otvaranje. ${ }^{79}$

Zar danas uopće ima dijaloga između književnosti, umjetnosti općenito i napose filozofije, s jedne strane, i politike, s druge? Ako ga nema, znači li to da za takvim dijalogom nitko ne osjeća potrebu?

\subsection{Zrinsko-frankopanska urota i hrvatska povijest}

Danilo Pejović prepoznao je Hrvatsko proljeće kao povijesni događaj za hrvatski narod.

»[Č]ini nam se kao da aktivno sudjelujemo u povijesnom zbivanju, - nakon duge stanke. «80

Bio je učesnik u događajima. Sam o tome kaže:

»U jednom razdoblju svog života najviše sam sudjelovao u Hrvatskom proljeću. $\ll^{81}$

O Zrinsko-frankopanskoj uroti pak kaže:

»Mi se sjećamo naše prošlosti i spominjemo se tristote obljetnice Zrinsko-frankopanske urote, mi hoćemo da nikada ne bude zaboravljen dan njihove tragične pogibije u Bečkom Novom Mjestu 30. travnja 1671. Tragična je njihova smrt (...) iznad svega zato što su živjeli i umrli za veliku stvar, za najveću stvar svakoga naroda - slobodu. Mi se sjećamo i našega djetinjstva kada su svake godine 30. travnja na hrvatskim kućama vijorile narodne zastave s crnim florom, sjećamo se 30. travnja kao dana žalosti našega naroda. «82

Tako je nekad obilježavana Urota. Valja nam se zapitati: što je nama danas taj događaj naše povijesti? Ima li još uvijek tu memorijsku snagu ili je posve

71

Ibid., str. 89.

72

Ibid., str. 125 .

73

Ibid., str. 126.

74

Ibid.

75

Ibid.

76

Ibid., str. 127.

77

Ibid., str. 130.
78

Ibid., str. 138.

79

Ibid., str. 145.

80

Ibid., str. 147.

81

Danilo Pejović, »Filozofija danas. Razgovor na Trećem programu Hrvatskog radija « (intervju), Republika LXI (2005) 11-12, intervju (razgovarao Vojo Šiljak), str. 217-225, str. 217.

82

D. Pejović, Duh i sloboda, str. 147. 
izblijedio? Ako je izblijedio, ima li to posljedica po naš identitet i budućnost? Pejović se zalaže za filozofsko-povijesni pristup Uroti jer je ona već bila književna, povijesna, kulturna, politička i gospodarska tema. Na primjeru Urote prepoznaje stalne obrasce djelovanja svih hrvatskih povijesnih ličnosti i pokazuje neke konstante hrvatske povijesti: Hrvatska je sama. Kasniji naraštaji hrvatskih političara nisu izvukli pouke iz Urote: ni Jelačić, ni Kvaternik, pa ni Radić i Supilo.

»Najteži korak u povijesti nekog naroda koji od bespravnoga puka hoće da postane politički narod, jest osiguranje njegove državnosti, kako unutra tako i van (...), najteži je i upravo zato najopasniji taj posljednji korak k potpunoj suverenosti: da kao samostalan čimbenik uredi svoju zemlju kako njemu najbolje odgovara, i odnose s bližim i daljim susjedima u skladu sa svojim dugoročnim životnim interesima. ${ }^{83}$

Taj povijesni korak dogodio se hrvatskom narodu nažalost u ratu s mnogo razaranja i žrtava. Uređujemo li svoju zemlju danas onako kako nam najbolje odgovara? Jesmo li osvijestili svoje nacionalne interese u skladu s kojima ulazimo u svjetske integracije i uređujemo odnose sa svojim susjedima? Potom Pejović kaže:

»... politička je suverenost zato prvi uvjet za gospodarsku i kulturnu, a ne obrnuto, kako su vjerovali svi naši utopisti do dana današnjega. ${ }^{84}$

To je još jedna potvrda ispravnosti njegovih uvida od prije pola stoljeća, kao i da nam valja više pozornosti posvetiti njegovom opusu općenito, a ovim temama koje zalaze u političku filozofiju osobito.

\subsection{Hrvatska kulturna orijentacija godine 1971 .}

Pejović piše u časopisu Dubrovnik 1971. godine:

»U sklopu općega poleta što nosi suvremeni socijalistički preporod hrvatskoga naroda, počeli smo i mi razmišljati o potrebi da napravimo iscrpnu i obuhvatnu bilancu svega što smo učinili posljednjih četvrt stoljeća, gdje smo zatajili, u čemu nismo uspjeli, kako bismo se zajedničkim snagama približili odgovoru: što nam je činiti narednih godina, u posljednjoj četvrtini dvadesetoga stoljeća? 85

Pejović kaže da je hrvatska inteligencija tradicionalno oporbena i poslovično buntovna. Hrvatska lijeva inteligencija smatra da može biti

»... ponosna što njezine još predratne ideje svugdje trijumfiraju. Ona se u ratu u golemoj većini opredijelila za revoluciju, tako ona danas daje svoj prilog nacionalnom i socijalnom programu demokratskog socijalizma. $\ll^{86}$

Politika i kultura su javna stvar; one se ontološki podudaraju, a ontički razlikuju. Osebujnost kulture 20. st u svijetu i Hrvatskoj jest doba tehnike. Tehnika bitno određuje suvremenu kulturu.

»Kome i kako u nas danas služe ti masovni mediji od novina i televizije? Čije je to vlasništvo? (...) Postoji li obratan utjecaj općinstva na masovna sredstva? Tko koga o čemu obavješćuje i ne obavješćuje i 'manipulira'? «87

Riječi koje kao da su danas napisane. Doista, tko su vlasnici masovnih medija, čemu i kome služe? Tko koga i o čemu danas obavještava i manipulira? Za ondašnja sredstva masovnog priopćavanja kaže da se nisu uklapala u hrvatsku kulturu. Isto to pokazuje na primjeru školstva i visokog školstva kao važnih i integralnih dijelova nacionalne kulture. Što reći za našu sliku u svijetu? Treba nam još nenapisana velika sistematska »kulturna povijest Hrvata«. Velika hrvatska kulturna baština čeka i zove svoje istraživače. 
»Juraj Šižgorić, Ivan Česmički, Ludovik Crijević, Ilija Crijević, Karlo Pucić; Jakov Bunić, Damjan Benešić, i Antun Vrančić još uvijek čekaju svoje prve monografije (...), mogli bi na prste prebrojiti one koji su pisali o Boškoviću i Getaldiću (...), malo znamo o takvim polihistorima kakvi bijahu Marko Antonije Gospodnetić, Ivan Lučić, Stjepan Gradić, Juraj Ratkaj! Posebno poglavlje tvori povijest hrvatske filozofije. $\ll^{88}$

Možemo tek ustvrditi, unatoč pomacima, da je pred nama mnogo posla, čak i pedeset godina nakon što su napisane te Pejovićeve riječi. Smatrao je da je vrijeme da Hrvati sto godina nakon Strossmayera dobiju svoju Hrvatsku akademiju. Bio je jedan od onih koji je sanjao Collegium croaticum.

»Tako bi za nas izgledali glavni elementi hrvatske kulturne orijentacije A. D. 1971. Kad kultura prestane biti nečiji balast i sirotica, 'nezgodni kulturni sektor' otkrit će se kao deficijentni modus duhovnoga bitka hrvatskoga naroda, koji danas obvezuje cijelu narodnu zajednicu i svakog pojedinca kome je povijest dosudila da mu pripada. « ${ }^{89}$

\subsection{Otvorenost hrvatske kulture}

Istoimeni Pejovićev rad objavljen je u Hrvatskom znanstvenom zborniku Matice hrvatske 1971. godine kao njegova svojevrsna programska orijentacija. Pejović kaže da, pored umjetnosti i književnosti, u sklopu kulture jednoga naroda valja promišljati i znanost. Dapače, on upravo postavlja pitanje o tome u kakvu je stanju hrvatska znanost te 1971. godine. Smatra da je cilj hrvatske znanosti služiti čovjeku i čovječanstvu.

»Ma kako bile univerzalne, znanstvene su istine $\mathrm{u}$ isti mah vjerodostojna svjedočanstva o prostoru i vremenu svoga nastanka, jer i znanstveno je istraživanje nerazdvojiv dio kulturnog života pojedinca i naroda. ${ }^{90}$

Zalaže se da stranice HZB-a budu posvećene jedinstvu znanosti koje je uvjet znanstvenog istraživanja današnjice. Kao što se znanost ne smije zatvarati pred filozofijom, tako se ni filozofija ne smije zatvarati pred znanošću. Otvorenost hrvatske znanosti kao dijela narodne kulture potvrđuje se u njenoj univerzalnosti, »što pokazuje njena bogata povijest od početaka novoga vije$\mathrm{ka}$, ona je uvijek bila integralan dio evropske i svjetske znanosti i po svojoj tematici i po mjestu djelovanja svojih protagonista «. ${ }^{91} \mathrm{Ti}$ se protagonisti uistinu mogu pratiti od Jurja Dragišića do Lavoslava Ružičke. Tema nije samo kriterij doprinosa naših znanstvenika u svijetu i Hrvatskoj nego i ozbiljnost istraživanja područja kojim se bavi.

»Naposljetku, kao što svaki od nas, ukoliko je čovjek, svugdje sudjeluje u ostvarenju ideje čovječnosti i čovječanstva, prirodno je da ideju čovjeka ponajprije ostvarujemo u svom narodu, i da našu prisutnost u svijetu naziremo već u svojoj zemlji. Samo ćemo tako svojim znanstvenim istraživanjima otkrivati punu istinu o suvremenom svijetu kao cjelini, i postepeno ostvarivati plemenitu težnju da znanost učini sve za bolje razumijevanje među narodima i da pridonese miru u svijetu. ${ }^{92}$

83

Ibid., str. 152 .

84

Ibid., str. 153

85

Ibid., str. 155

86

Ibid., str. 158

87

Ibid., str. 157

\section{8}

Ibid., str. 158.

89

Ibid., str. 159.

90

Ibid., str. 162.

91

Ibid.

92

Ibid 
Dalje se Pejović pita ima li danas u globaliziranom svijetu planetarne tehnike i masovnih medija (dodajmo i Interneta kojega nije bilo prije pedesetak godina) ikakvog smisla baviti se kulturom malih naroda?

»Stojimo li doista pred neviđenim procvatom jedne jedinstvene svjetske kulture? (...) Kako stoji s kulturom takva malog naroda kao što je hrvatski? Koje su bitne značajke te kulture, i gdje se one najjače očituju? Napokon: kakav je odnos Hrvatske spram evropske i svjetske kulture, naime kulture velikih naroda, Evrope i svijeta kao cjeline? «33

Pejović smatra da ni prije ni sada ne nedostaje »teorija « koje smatraju da veliki narodi i njihove kulture trebaju asimilirati male. U takvim okolnostima pitanje kulture malih naroda pitanje je njihova opstanka jer »narod bez svoje kulture više nije narod «. ${ }^{94}$ Ima mnogo naroda koji su nestali s povijesne scene, počevši od antike do danas, ali ima i suprotnih primjera:

»... naime da neki mali narodi tisućljećima zrače svoju kulturu kao stalnu inspiraciju svim evropskim, pa i svjetskim narodima (...). Kultura naroda [je] sabiranje svih njegovih bitnih očitovanja, i njihovo čuvanje u spomenicima od najstarijih vremena do danas. U tim se spomenicima objavljuje 'narodna duša' i potvrđuje 'objektivni duh' svakoga naroda, kao i pojedinaca koji su time obuhvaćeni i određeni.«"

Zatim, Pejović dodaje da kulturu svakoga europskoga naroda bitno određuju četiri kategorijalna elementa:

1. zajednički europski izvori,

2. posebna narodna tradicija,

3. uzajamni utjecaji,

4. vlastito izvorno stvaralaštvo.

Svi oni u svojoj cjelini tvore, po mišljenju Pejovića, kategorijalnu strukturu kulture. Time smo, kaže Pejović, opremljeni za poimanje bîti svake, pa tako i hrvatske kulture u njezinoj općenitosti, posebnosti i jednokratnosti, tj. neponovljivosti. Time je postavio okvir za razumijevanje ustroja hrvatskoga duha. Zajednički europski izvori, primijenjeni na poimanje hrvatske kulture, pokazuju da se hrvatska kultura bitno ustrojava na razmeđu između Istoka i Zapada, Okcidenta i Orijenta, proširujući i dopunjujući ga elementima istočnoeuropske i islamske kulture, što ostali zapadnoeuropski narodi (osim španjolskoga) nemaju.

»Podrijetlom s Istoka, okrenuta Zapadu, izazvana a kasnije potaknuta i Orijentom, ta je kultura po otvorenosti svojih izvora i širine horizonata jedinstvena ne samo u Evropi nego i u svijetu (...), upravo zahvaljujući toj svojoj bitnoj otvorenosti (...). Hrvatska je kultura, kroz trinaest stoljeća znala odoljeti samobitnost (...). Ona odbija izolaciju. Njezina je tradicija - (...) - stalna inovacija, ona odbija izolaciju, jer upravo zahvaljujući svojoj bitnoj otvorenosti, hrvatska je kultura ostala hrvatska i danas jest kultura. ${ }^{96}$

Potom Pejović navodi njene najznačajnije posebnosti, dakle one koje se javljaju jedino u hrvatskoj kulturi:

1. Kao rijetko koji narod u Europi, Hrvati su razvili latinsku pismenost i književnost od 9. do 19. st., koja je značajan dio hrvatske i europske književnosti i kulture. Zadnji su u svom parlamentu ukinuli latinski jezik tek 1847. godine.

2. Ona se usporedno s latinskim razvijala od početka na narodnom jeziku. Hrvatski je narod imao bogoslužje na narodnom jeziku.

3. Hrvatska pismenost razvila se na tri europska pisma: glagoljici, bosanskohrvatskoj ćirilici i latinici te aljamiado književnost na arapskom jeziku.

4. Hrvatska je kultura tematsko-sadržajno, često stilski i djelomično jezično povezana s Orijentom. 
5. Novovjekovna filozofija i znanost do 19. st. pisane su na latinskom jeziku.

6. Hrvatsko prosvjetiteljstvo promiču svećenici i redovnici.

7. Okrenuta je Zapadu, ali je vezana za Istok.

»Panslavizam, austroslavizam i jugoslavizam po svom su podrijetlu tipično hrvatske ideje. ${ }^{97}$

Ovako sustavno, jezgrovito i raščlanjeno navedene posebnosti hrvatske kulture mogu biti dobro polazište za njihovu širu elaboraciju i produbljeno kulturološko istraživanje. No naša kultura ima i svoje naličje.

»Nedostatak smisla za realnost, pretjerani idealizam i naglašena praslavenska osjećajnost. Zato je veliki idealist Juraj Križanić, poznavajući sebe i svoj narod, mogao reći: 'Uzrokom je svim i najvećim nevoljama našega naroda, što sami sebe ne poznajemo, a tuđincima vjerujemo’.«"

Promišljajući o reformi hrvatskoga visokog školstva, a polazeći od naših osebujnih potreba, Pejović se zalaže za dostizanje i održanje europskih i svjetskih standarda visokog školstva. Naime, u cilju našeg uključivanja u 21. stoljeće, zalaže se da u Hrvatskoj stvorimo nove institucije koje bi nam pomogle djelatno se uključiti u nadolazeće tokove i izazove, pa tako čitamo:

»Postojeći Interuniverzitetski centar za postdiplomske studije u Dubrovniku što prije transformirati u međunarodno sveučilište, nalik na Europsko sveučilište zemalja EZ u Firenci. U Zagrebu pak osnovati otvorenu izvansveučilišnu ustanovu s besplatnim predavanjima na najvišoj razini i za starije slušače o graničnim pitanjima suvremene znanosti, umjetnosti i filozofije (...). To bi bio naš Hrvatski kolegij College de Croatie! «99

Imamo li sluha za te njegove riječi koje u sebi sažimaju jednu novu nasušno potrebnu kulturnu orijentaciju. Danilo Pejović poručuje nam da kao postkomunistička zemlja imamo zadaću prihvaćanja principa slobode i najviših dostignuća moderne, kao traženja novih odnosa Istoka, Zapada i »trećeg svijeta«, da nam se ne bi dogodila restauracija predkomunističkih i predmodernih oblika života, kamo vode neke tendencije u postkomunizmu. Moderna ima još za nas emancipacijskih potencijala, ali pri tome Pejović ukazuje na $d v o j-$ benost » principa slobode « i njegovu deficitarnost jer ju moderna samo verbalno zastupa, »ali kao što najnovije iskustvo povijesti nedvosmisleno potvrđuje (agresija i 'etničko čišćenje' u Hrvatskoj i Bosni npr.) ne mari mnogo za to što se on univerzalno više realno ne ostvaruje ${ }^{100} \mathrm{Na}$ kraju, Pejović zabrinuto konstatira da pred našim očima nestaje humanistička tradicija kršćanske Europe i pita se ne nastupa li to povratak u prvobitno »prirodno stanje « nasilja i bezakonja.

\subsection{Hrvatski filozofi}

Pejović nije objavio radove o hrvatskim filozofima, ali je ukazivao na vrijednost i značaj njihova doprinosa europskoj filozofskoj baštini, pa stoga kaže:

93

Ibid., str. 163.

94

Ibid.

95

Ibid., str. 164.

96

Ibid., str. 167.
97

Ibid., str. 169.

98

Ibid., str. 170.

99

D. Pejović, Oproštaj od moderne, str. 172.

100

Ibid., str. 195. 
»Kao mali narod mi možemo biti ponosni što su i hrvatski humanisti kao učeni ljudi u tim svjetskim pokretima odigrali značajnu filozofsku ulogu potvrdivši time vidno svoju misaonu zrelost i našu duhovno-povijesnu suvremenost. ${ }^{101}$

To su svakako Petrić, Vlačić, Marulić, Bošković i drugi. Tekst »Filozofi starog Dubrovnika «102 Pejović je emotivno i potreseno pisao pod dojmom stradanja toga grada i područja njegove negdašnje Republike u ratnim razaranjima 1991. godine. To je njegov apel za pomoć Dubrovniku kao republici duha.

\title{
Mladen Živković \\ Danilo Pejović - ein Lehrer des Denkens
}

\begin{abstract}
Zusammenfassung
Pejović verkörpert in seiner Person das ursprüngliche philosophische Ethos und die Gelehrsamkeit. Die Stärke seines Denkens spiegelt sich in der verfeinerten Analyse des Themas wider. Sein literarisches Talent ist klar und er fühlt sich wie ein Virtuose und ein Künstler von Worten und Stil, der stellenweise poetisch ist. Er spricht leicht über die schwierigsten Themen der Philosophie. Er besitzt einen klaren, lehrreichen und enthusiastisch angemessenen, verfeinerten und raffinierten Ausdruck, der über alle unsere philosophischen Autoren hinausgeht. Dies wird bereits in den Titeln seiner Bücher, Studien, Aufsätze und Artikel sichtbar, die die Tiefe seiner Bedeutung angeben, und als würde die Bedeutung des gesamten Textes in ihnen selbst liegen. Obwohl nicht der Einzige, zeigte Pejović, dass es möglich war, anders zu denken, neue Perspektiven zu öffnen, sich der Zukunft zu öffnen, indem man aus dem marxistischen Regenmantel herauskommt, in den wir fast alle gehüllt waren. Professor Pejović demonstriert, wie sich die Evolution entwickeln kann, um auf Kommendes, Neues und Andersartiges zu treffen. Natürlich ist das Neue und Andersartige allein dadurch nicht schon hier, aber um neue Horizonte zu eröffnen, müssen wir gegen die Strömung vorgehen. Das Opus von Professor Pejović sollte als eine Richtung verstanden werden, die uns auffordert, mit uns selbst umzugehen, uns vorzustellen, wie es mit uns war, wie es ist und wie es sein sollte. Seine Reflexion über das Thema des kroatischen Nationalschicksals, betrachtet durch die Reflexion über unser Erbe, unsere Kultur, unsere Geschichte und unsere Gesellschaft und Politik, hat der Fromme auf einer beneidenswerten Denkstufe eines engagierten Philosophen geschaffen, mit dem bei uns wenige zu vergleichen sind. Genau heute verdanken wir es ihm und geben ihm die Ehre, sich diesem thematischen Kreis geöffnet zu haben. Seine Gedanken sind für uns unvermeidlich und verbindlich. Wir denken, dass gerade jetzt der richtige Moment ist, um sein Werk im Allgemeinen und diesen Aspekt im Besonderen zu lesen. Mit diesem kurzen Überblick möchten wir nur auf seinen Beitrag zu unserer Philosophie und Kultur hinweisen. Er bleibt extrem aktuell und anregend. Wir hoffen, dass diese Arbeit dies ausreichend begründet hat. Wenn dieser Text unsere jungen Philosophen und Philosophinnen dazu anregt, seine Werke zu studieren, dann würde diese Arbeit seinen Zweck erfüllen. Mögen seine Worte sie erreichen, die Worte des Denklehrers, laut denen das „Denken nur auf jene Weise lebt, indem es in der Suche und in der Frage bestehen bleibt".
\end{abstract}

\section{Schlüsselwörter}

Danilo Pejović, Philosophie, Geschichte, Wissenschaft, Technik, Ästhetik, Kultur, Offenheit, kroatische Kultur

101

D. Pejović, Duh i sloboda, str. 22.
102

Usp. ibid., str. 175. 